\title{
АНТАГОНИЗМ НОВЫХ ИЗОЛЯТОВ ГРИБОВ РОДА TRICHODЕRМА ПО ОТНОШЕНИЮ К ПАТОГЕНУ ALTERNARIA SP., ВЫДЕЛЕННОМУ ИЗ ОРЕХА ГРЕЦКОГО
}

\author{
Щербакова Т.И., Кручан Ш., Пынзару Б.В., Воломук Л.Ф. \\ Институт Генетики, Физиологии и Защиты растений Молдовы \\ e-mail: tscerb@gmail.com
}

\begin{abstract}
The research is aimed at studying the antagonistic relationships of five isolates of the genus Trichoderma fungi in relation to the Alternaria sp. fungus. The pathogen was isolated from diseased walnut leaves. In the work was used the method of double cultures on agar media. As a result,
\end{abstract}


the inhibition rate of Alternaria pathogen by Trichoderma fungi was determined. For isolate №3 the rate was $90 \%$, for isolate №2 - 85\%, isolate №4 inhibited the pathogen by $75 \%$, isolate №1 - by $65 \%$. Isolate №5 and strains T.virens and T. lignorum suppressed the growth of Alternaria by 40-50\%.

Key words: antagonism, Trichoderma isolate, Alternaria pathogen, walnut

\section{Введение}

В первой половине вегетационного периода 2020 года, в силу сложившихся погодных условий, отмечено большое распространение и развитие грибов рода Alternaria. Они выделялись из многих однолетних и многолетних культур, дикорастущих растений, сорняков и насекомых-вредителей. Многие виды Alternaria вызывают пятнистости листьев, вредоносность которых проявляется в повреждении фотосинтетического аппарата растения и при сильном заражении приводят к существенным потерям урожая. Плесневение и гниение семян, плодов и корнеплодов ещё один тип вреда, причиняемого видами Alternaria, приводит к ухудшению внешнего вида продукции и её выбраковке [1]. Виды Alternaria обладают способностью продуцировать более 70 токсинов, которые могут накапливаться в зараженной сельскохозяйственной продукции. Они играют важную роль в патогенности грибов и вызывают проблемы, связанные с безопасностью пищевых продуктов, поскольку некоторые из них особо опасны для людей и животных. Токсины Alternaria сохраняются в процессе переработки заражённых плодов и обнаруживаются, например, в томатной пасте, в томатном и яблочном соках, в красном вине и т.д. [2, 3].

В исследованиях последнего времени отмечается, что часто несколько микотоксинов Alternaria могут одновременно встречаться в загрязненных пищевых продуктах и усиливать их общую токсичность [3].

Виды Alternaria в большинстве своём способны развиваться при умеренной температуре и наличии капельной влаги в виде дождей или обильных рос [1].

Для снижения развития и распространения грибов Alternaria, уменьшения их вредоносности и снижения пестицидной нагрузки, часто рекомендуют использовать биологические препараты для защиты растений на основе живых микроорганизмов, в том числе грибных биопрепаратов на основе Trichoderma. Наши исследования направлены на изучение антагонистического действия выделенных в этом году новых изолятов грибов Trichoderma по отношению к патогену Alternaria sp., выделенному из листьев грецкого ореха.

\section{Материалы и методы}

Объектами исследований являлись 5 изолятов грибов Trichoderma, выделенных из природных субстратов в 2020 году и изолят Alternaria, выделенный их листьев грецкого ореха. Также в экспериментах использовались штаммы Trichoderma virens CNMN-FD-13, 3X и T.lignorum CNMN-FD-14, M-10, продуценты биопрепаратов Gliocladin-SC и Trichodermin-SC, соответственно. Изоляты №1-3 и 5 выделены из разных почвенных субстратов произрастания ореха грецкого, №4 выделен из листьев opexa.

Антагонистическую активность изолятов Trichoderma по отношению к патогену Alternaria изучали методом встречных (двойных) культур на агаризованной суслоагаровой питательной среде (пивное сусло-вода 1:1), повторность трехкратная. Культивировали при температуре $25^{\circ} \mathrm{C}$, оптимальной для исследуемых грибов [4]. Радиус колоний измеряли ежедневно линейным методом (мм) от края посеянного блока к центру чашки, на 5-е сутки вычисляли показатель ингибирования патогена грибом Trichoderma (\%). На 10-е сутки определяли тип взаимоотношений 
изолятов Trichoderma и фитопатогена и оценивали в баллах степень нарастания антагониста на колонию патогена: 0 баллов - нарастания нет, 1 балл - антагонист занимает 25\% площади колонии патогена, 2 балла - антагонист занимает 25-50\% колонии патогена, 3 балла - антагонист занимает 51-75\% колонии патогена, 4 балла антагонист занимает 76-100\% площади колонии патогена [5]. Проводили микроскопирование грибов в зонах смыкания колоний и зонах нарастания.

\section{Результаты и обсуждения}

Погодные условия в начале вегетационного периода являлись благоприятными для развития альтернариоза на большинстве культурных, дикорастущих и сорных растениях. Повышенная влагообеспеченность в мае, июне и июле - 263 мм выпавших осадков при норме 181 мм, а также температурные показатели в мае на 2,6 $6^{0}$ ниже нормы, а в июне на $1,4^{0} \mathrm{C}$ выше нормы, способствовали развитию альтернариоза растений на однолетних и многолетних культурах [6]. Альтернариоз отмечен на томатах, сое, зерновых, подсолнечнике и др. Из пятен на листьях яблони, груши, вишни, черешни выделялись грибы Alternaria. Сильное альтернариозное поражение отмечено на можжевельнике, вплоть до гибели ветвей. Из пораженной листвы ореха грецкого выделено в чистую культуру 2 среднеспоровых вида патогена и еще один крупноспоровый вид отмечен на коре дерева (при посевах на питательные среды формировались конидии среднего размера) (рис. 1).

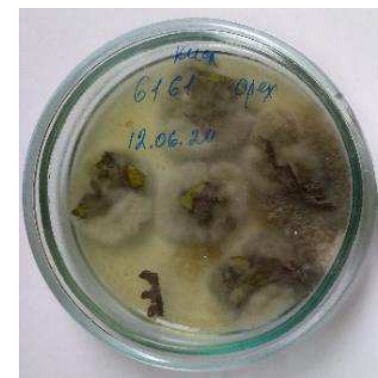

a)

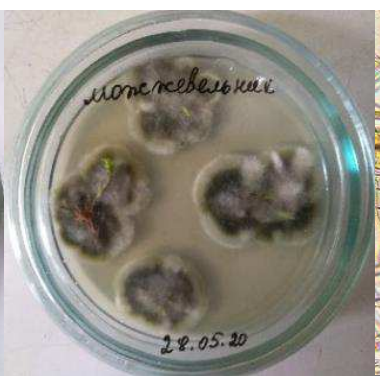

b)

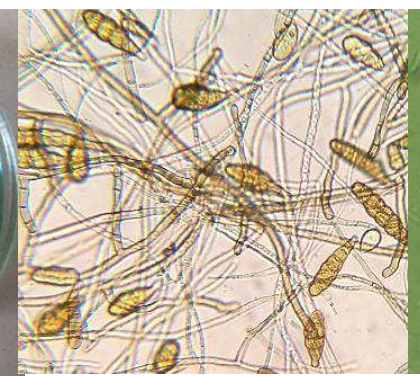

c)

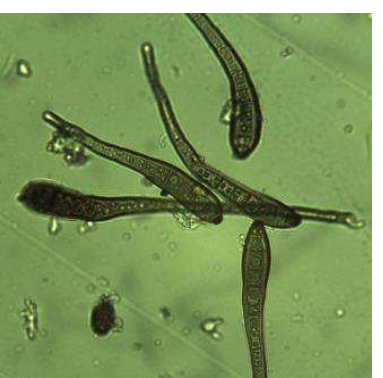

d)

Рис. 1. Фитопатогенный гриб Alternaria. a-b) - выделение патогена из листьев ореха грецкого и хвои можжевельника, c) - конидии и мицелий с листьев ореха, увеличение в 400 раз, d) - конидии с коры дерева ореха, увеличение в 400 раз

Однако погодные условия 2020 года были благоприятными и для грибовантагонистов фитопатогенов, из природных субстратов выделялись аборигенные грибы рода Trichoderma. Антагонистические взаимоотношения выделенных изолятов и Alternaria определяли методом двойных (встречных) культур. Грибы Trichoderma являются быстрорастущими, в двойной культуре в течение четырех суток колонии изолятов № 1, 2, 3, 4 и штамм T.lignorum достигли размера $80 \times 80$ мм и заселили всю чашку. Изолят №5 и штамм T.virens максимально заселили чашку на пятые сутки. Размеры колонии Alternaria различались: в культуре с изолятом №3 радиус колонии патогена на 10-е сутки составил 2 мм, с изолятом № $2-3$ мм, с изолятом № $4-5$ мм. Изолят №1 позволил патогену вырасти на 7 мм, а №5 - на 12 мм. В культуре со штаммом T.virens радиус колонии патогена составил 10 мм, со штаммом T.lignorum - 11 мм (табл. 1, рис. 2). 
Таблица 1. Характеристика антагонистических взаимоотношений изолятов Trichoderma и патогена Alternaria в двойной культуре

\begin{tabular}{|c|c|c|c|c|c|c|c|c|}
\hline \multirow[t]{2}{*}{$\begin{array}{l}\text { Изолят, } \\
\text { штамм }\end{array}$} & \multicolumn{6}{|c|}{$\begin{array}{l}\text { Радиус колоний грибов, мм } \\
\text { Время измерения, сутки }\end{array}$} & \multirow{2}{*}{$\begin{array}{c}\text { Показатель } \\
\text { ингибирования } \\
\text { на 5-е сутки, \% }\end{array}$} & \multirow{2}{*}{$\begin{array}{l}\text { Степень нарас- } \\
\text { тания изолятов } \\
\text { на патоген, балл }\end{array}$} \\
\hline & 1 & 2 & 3 & 4 & 5 & 10 & & \\
\hline Trichoderma sp. 1 & 9 & 30 & 54 & 80 & 80 & 80 & 65 & 4 \\
\hline Alternaria sp. & 0 & 2 & 5 & 7 & 7 & 7 & 0 & \\
\hline Trichoderma sp. 2 & 14 & 42 & 70 & 80 & 80 & 80 & 85 & 3 \\
\hline Alternaria sp. & 0 & 2 & 3 & 3 & 3 & 3 & 0 & \\
\hline Trichoderma sp. 3 & 10 & 40 & 65 & 80 & 80 & 80 & 90 & 4 \\
\hline Alternaria sp. & 0 & 2 & 2 & 2 & 2 & 2 & 0 & \\
\hline Trichoderma sp. 4 & 14 & 41 & 70 & 80 & 80 & 80 & 75 & 4 \\
\hline Alternaria sp. & 0 & 4 & 5 & 5 & 5 & 5 & 0 & \\
\hline Trichoderma sp. 5 & 12 & 28 & 46 & 60 & 80 & 80 & 40 & 1 \\
\hline Alternaria sp. & 0 & 6 & 10 & 12 & 12 & 12 & 0 & \\
\hline T.virens $3 \mathrm{X}$ & 11 & 28 & 48 & 62 & 80 & 80 & 50 & 4 \\
\hline Alternaria sp. & 0 & 3 & 8 & 10 & 10 & 10 & 0 & \\
\hline T.lignorum M-10 & 7 & 40 & 60 & 80 & 80 & 80 & 40 & 0 \\
\hline Alternaria sp. & 0 & 6 & 10 & 11 & 11 & 11 & 0 & \\
\hline $\begin{array}{l}\text { Alternaria sp. } \\
\text { Контроль }\end{array}$ & 0 & 6 & 10 & 15 & 20 & 46 & 0 & - \\
\hline $\mathrm{HCP}_{0,05}$ & & & & & & 18 & 23 & \\
\hline
\end{tabular}

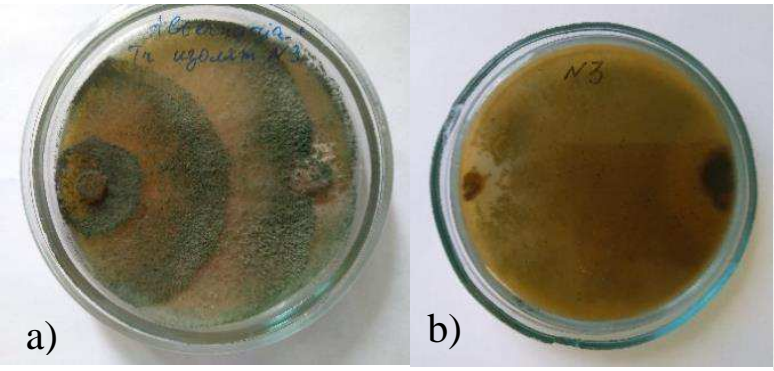

Изолят №3
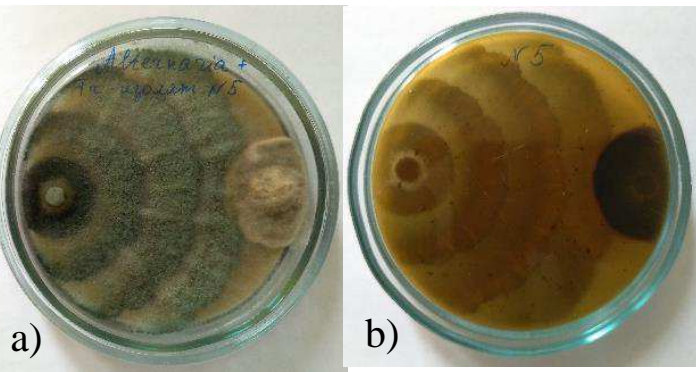

Изолят № 5

Рис. 2. Изоляты Trichoderma в двойной культуре

a) - лицевая сторона чашек, b) - реверс, 10-й день роста

Показатель ингибирования патогена Alternaria грибом Trichoderma для изолята №3 составил 90\%, для изолята №2 - 85\%, изолят №4 ингибировал патоген на $75 \%$, а №1 - на 65\%. Изолят №5 и штаммы T.virens и T.lignorum подавляли рост Alternaria на 40$50 \%$ (табл. 1). На 10-е сутки проводили микроскопирование грибов в зонах смыкания колоний и зонах нарастания. В препаратах, приготовленных из зон смыкания культур, наблюдалось ингибирование мицелия, его утончение, деформация и разрушение (характерно для всех изолятов и штаммов). Образования конидий не отмечено. В зонах нарастания, ближе к стенке чашки успели образоваться конидии, но многие из них разрушались под воздействием метаболитов Trichoderma (рис. 3). 


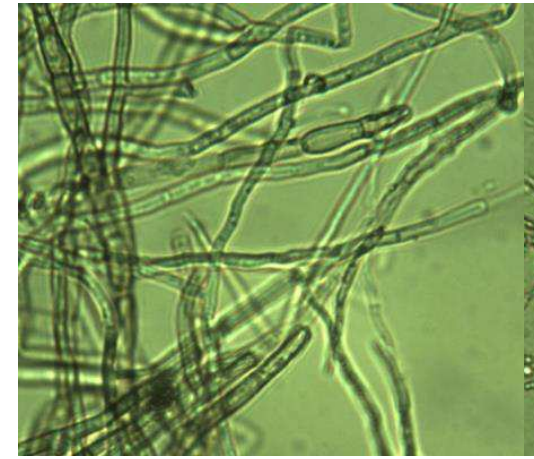

a)

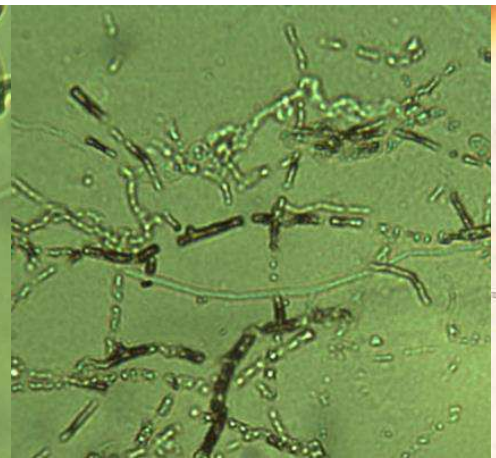

b)

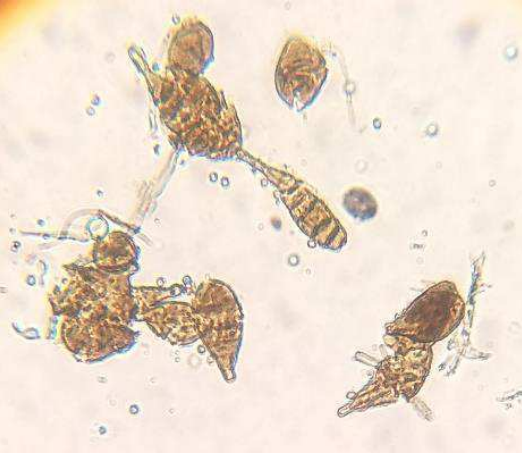

c)

Рис. 3. Мицелий и конидии Alternaria, увеличение в 400 раз

a) - здоровый мицелий Alternaria в контроле, b) - разрушение мицелия и- c) - конидий под воздействием гриба Trichoderma

В результате проведенных исследований было определено, что изоляты Trichoderma №№1, 2, 3, 4 и штамм T.virens проявляют фунгистатический алиментарный (односторонний) антагонизм, при котором происходит нарастание колонии гриба Trichoderma на поверхность колонии фитопатогена и патоген прекращает активный рост. Этот тип антагонизма особо выразительно проявился у изолята №3, когда в двойной культуре рост гриба Alternaria был направлен не к центру чашки, а в противоположную, к стенке, где оставалось 5-7 мм пространства. По-видимому, биологически активные вещества этого изолята диффундировали в питательную среду и воздействовали на патоген, прекращая его рост практически сразу после посева. Возможна активность летучих метаболитов изолята.

Изолят №5 также проявил фунгистатический алиментарный антагонизм, но в слабой форме. Штамм T.lignorum проявил территориальный антагонизм - обрастание колонии патогена благодаря высокой скорости роста. Нарастания на патоген не происходило, но его рост снижался.

\section{Выводы}

В результате проведенных исследований установлено, что из пяти новых изолятов грибов рода Trichoderma, выделенных из субстратов произрастания ореха грецкого, четыре проявляют антагонизм к фитопатогенному грибу Alternaria sp., выделенному из пораженных листьев ореха. Изоляты могут быть использованы для разработки биологических средств защиты растений от альтернариоза.

\section{Библиография}

1. Ганнибал Ф.Б. Мониторинг альтернариозов сельскохозяйственных культур и идентификация грибов рода Alternaria. Методич. пособие. С.-Петербург, 2011, 71 с.

2. Scott P.M., Lawrence G.A., Lau B. P.-Y. Analysis of wines, grape juices and cranberry juices for Alternaria toxins. J. Mycotoxin Research, 2006, Vol. 22 (2), p. 142-147.

3. Hyang Burm Lee, Patriarca A., Naresh Magan. Alternaria in food: ecophysiology, mycotoxin production and toxicology. J. Mycobiology, 43 (2), 2015, p. 93-106.

4. Alternaria in Food: Ecophysiology, Mycotoxin

5. Comporota A. Antagonisme in vitro de Trichoderma spp. vis-a-vis de Rhizoctonia solani Kuhn. Agronomie. 1985, vol. 5, p. 613-620. 
6. Поликсенова В.Д., Храмцов А.К., Пискун С.Г. Методические указания к занятиям по разделу «Микология. Методы экспериментального изучения микроскопических грибов». Минск: БГУ, 2004, 36 с.

7. Pogoda i klimat. http://www.pogodaiklimat.ru/archive.php. (дата обращения 15.08.20). 